\title{
Neuropati Optik Traumatik: Gambaran 13 Kasus Berdasarkan Radiologi dan Awitan Terapi Kortikosteroid di Rumah Sakit Cipto Mangunkusumo
}

\author{
Made Paramita Wijayati ${ }^{1}$, Syntia Nusanti², M. Sidik ${ }^{2}$ \\ ${ }^{1}$ Program Fellowship Departemen Ilmu Kesehatan Mata, Rumah Sakit Cipto Mangunkusumo, Jakarta, Indonesia \\ ${ }^{2}$ Departemen Ilmu Kesehatan Mata, Universitas Indonesia, Rumah Sakit Cipto Mangunkusumo, Jakarta, \\ Indonesia \\ E-mail: miethapratama@gmail.com
}

\begin{abstract}
ABSTRAK
Tujuan penelitian: neuropati optik traumatik adalah kondisi langka dan berpotensi mengancam penglihatan yang disebabkan oleh trauma mata atau kepala. Akson saraf optik dapat rusak baik secara langsung maupun tidak langsung. Penatalaksanaan neuropati optik traumatik dapat diamati, pemberian steroid atau dekompresi. Di pusat yang tidak dilakukan dekompresi, steroid dosis tinggi lebih disukai untuk pasien neuropati optik traumatik. Penelitian ini bertujuan untuk menganalisis karakteristik (usia rata-rata dan jenis kelamin, onset trauma, gejala terbanyak, ketajaman visual, refleks konsensual sebagai tanda), gambaran radiologi, dan awitan terapi kortikosteroid pada neuropati optik traumatik pasien.

Metode: penelitian ini merupakan penelitian deskriptif observasional yang datanya dianalisis secara retrospektif dari rekam medis.

Hasil: dari 13 kasus jenis kelamin yang paling banyak terkena adalah laki-laki (76,9\%). Rerata kelompok umur 32,85 $\pm 14,67$ tahun dengan penglihatan kabur dan perdarahan merupakan gejala yang paling umum, timbulnya trauma dibawah 24 jam (76,9\%), ketajaman penglihatan awal ada persepsi cahaya dan gerakan tangan dengan refleks konsensual negatif (76,9\%). Peningkatan ketajaman penglihatan dengan terapi kortikosteroid awal dibawah 24 jam sebanyak 7 kasus dan lebih dari 24 jam sebanyak 2 kasus. Dari 9 kasus dengan perbaikan ketajaman visual, terdapat 4 kasus dengan fraktur orbital dan 5 kasus tanpa fraktur orbita.

Kesimpulan: perbaikan visual dalam kasus kami lebih banyak terjadi pada terapi kortikosteroid awal lebih dari 24 jam dan tidak ada fraktur orbita.
\end{abstract}

Kata kunci: neuropati optik traumatik, gambaran radiologi, terapi kortikostreoid

\begin{abstract}
Introduction and Objection: Traumatic Optic Neuropathy is a rare and potentially vision-threatening condition caused by ocular or head trauma. The optic nerve axons may be damaged either directly or indirectly. The management of traumatic optic neuropathy could be observed, giving steroids or decompression. At center which optic nerve decompression is not routinely performed, high dose
\end{abstract}


steroid is preferred for traumatic optic neuropathy patients. The study aims to analyze characteristics (mean age and gender, onset trauma, most symptom, visual acuity, consensual reflex as a sign), radiology feature, and onset corticosteroid therapy on patient traumatic optic neuropathy.

Methods: This study was a descriptive observational case series which data retrospectively analysis from medical record.

Result: From 13 cases most common gender affected were males (76,9\%). The mean age group $32.85 \pm 14.67$ years old with blurry vision and bleeding are the most common symptom, the onset of trauma below 24 hours (76.9\%), the initial visual acuity is no light perception and hand movement with a negative consensual reflex (76.9\%). Visual acuity improves with initial corticosteroid therapy below 24 hours are 7 cases and more than 24 hours are 2 cases. From 9 cases with visual acuity improvement, there are 4 cases with orbital fracture and 5 cases without orbital fracture.

Conclusion: Visual improvement in our cases happened more on initial corticosteroid therapy more than 24 hours and no orbital fracture.

Keywords: Traumatic Optic Neuropathy, Corticosteroid therapy, Radiology Feature

\section{PENDAHULUAN}

$\mathrm{N}$ europati optik traumatik (NOT) adalah suatu kondisi yang sangat jarang serta berpotensi mengancam pengelihatan yang dapat disebabkan oleh cedera okuli dan kepala. ${ }^{1,2}$ Berdasarkan patofisiologinya, NOT diklasifikasikan sebagai direk dimana terjadi cidera langsung pada nervus optik dan indirek dimana kerusakan nervus optik terjadi secara tidak langsung. ${ }^{3}$ NOT direk biasanya disebabkan oleh laserasi atau avulsi nervus optik atau oleh karena fraktur kanal optik. Hal inilah yang menyebabkan terjadinya prognosis yang buruk. ${ }^{1}$ NOT indirek diakibatkan efek non-penetrasi dari trauma antara lain perdarahan, edema, dan gegar otak. ${ }^{4,5}$

Neuropati optik traumatik (NOT) terjadi sekitar $0,5-2 \%$ pada cedera kepala dan lebih sering terjadi pada fraktur kraniofasial. ${ }^{4}$ Amerika Serikat angka kejadian NOT terjadi sekitar $0,5-5 \%$ kasus pada pasien dengan cedera kepala berat ${ }^{6}$ dan di United Kingdom menemukan prevalensi NOT pada populasi umum sebesar 1 dalam 1.000.000 populasi. ${ }^{7}$ Di Indonesia, penelitian yang dilakukan oleh Mahayani dkk tahun 2013-2015 menyatakan terdapat 41 pasien NOT dan hanya 13 orang pasien yang diterapi kortikosteroid dosis tinggi. Dari 13 orang pasien ini 78,6\% adalah laki laki dengan usia terbanyak kurang dari 20 tahun. ${ }^{8}$ Penelitian yang dilakukan Daniel dkk di Rumah Sakit Cipto Mangunkusumo menyatakan dari Januari 2014-Desember 2015 terdapat 34 pasien NOT dimana $82,4 \%$ adalah laki-laki dan rerata usia 22,47 $\pm 10,68$ tahun. Pasien yang diterapi dengan metilprednisolon intravena sebesar $67,6 \%$ dan $26,5 \%$ diterapi dengan metilprednisolon oral $(0,8 \mathrm{mg} / \mathrm{kgBB} / \mathrm{hari}){ }^{9}$ NOT merupakan cedera akut dari nervus optikus dengan gangguan fungsi penglihatan. Penyebab spesifik meliputi kecelakaan sepeda dan sepeda motor, cedera kepala oleh karena jatuh, serangan luka tusuk dan luka tembak. ${ }^{4}$ Kerusakan pada nervus optikus menyebabkan immediate shearing dan menginduksi terjadinya pembengkakan sekunder pada axon Retinal Ganglion Cell (RGC) dan disertai degenerasi RGC selanjutnya mengakibatkan hilangnya RGC. ${ }^{6,10}$

Penurunan tajam penglihatan pada kasus NOT umumnya berlangsung cepat dan berat, namun dampak yang terjadi dapat tertunda pada $10 \%$ kasus. ${ }^{4}$ The International Optic Nerve Trauma Study $(\text { IONTS })^{11}$ menunjukkan hampir $40 \%$ kasus memiliki tajam penglihatan no light perception (NLP), dan hanya 10\% kasus memiliki tajam penglihatan tanpa koreksi $($ TPTK) $\geq 20 / 40$. Penurunan tajam penglihatan pada kasus NOT umumnya bersifat unilateral. ${ }^{3,4,11}$ 


\section{Penegakan diagnosis TON} didapatkan melalui dengan anamnesis dan pemeriksaan fisik, serta penunjang proses penegakkan diagnosis bukan merupakan kendala. Prediksi resiko berdasarkan kelainan radiologi mulai menjadi perhatian. Penelitian Bonadapally dkk ${ }^{12}$ tahun 2014 melakukan prediksi NOT setelah adanya trauma pada wajah berdasarkan CT scan. Waktu antara trauma dan dimulainya terapi diduga sebagai prediksi yang kuat untuk terapi NOT indirek. Terapi yang lebih awal diharapkan akan mendapatkan prognosis yang lebih baik. ${ }^{1}$ Tatalaksana NOT masih kontroversial, dan belum ditemukan pedoman penatalaksanaan yang jelas. ${ }^{3,4,5,7,11}$ Pada tahun 1990 kortikosteroid dosis tinggi dilaporkan merupakan terapi yang sukses dalam kasus cedera tulang belakang akut. Seiring tahun banyak penelitian yang menggunakan kortikosteroid dalam penatalaksanaan NOT. ${ }^{4}$ Sundep $\mathrm{dkk}^{13}$ tahun 2014 meyatakan dari hasil penelitiannya pada pasien pasien NOT oleh karena cedera kepala yang diakibatkan oleh kecelakaan lalu lintas atau terjatuh menunjukkan hasil kemajuan yang signifikan setelah diterapi methylprednisolone pada pasien yang memiliki tajam pengelihatan counting finger (CF) tetapi tidak pada pasien yang memiliki tajam pengelihatan yang sangat buruk. Penelitian oleh Daniel dkk 2018 menyatakan dosis methylprednisolone IV 1 gram/hari selama 3 hari dilanjutkan dengan penurunan dosis perminggu maupun pemberian preparat oral dengan dosis $0,8 \mathrm{mg} / \mathrm{kgBB} / \mathrm{hari}$ dapat digunakan. Studi IONTS tidak menemukan perbedaan antara terapi steroid dibandingkan dengan intervensi bedah atau tanpa intervensi dengan $52 \%$ yang menerima steroid menunjukkan peningkatan visual dari tiga garis atau lebih dibandingkan 57\% pada kelompok observasi. Studi menyimpulkan bahwa baik dosis maupun waktu terapi steroid tidak berpengaruh pada perbaikan tajam pengelihatan. ${ }^{11}$ Karena adanya kontroversi pada terapi ini peneliti ingin melihat bagaimana hasil pemberian terapi steroid pada kasus NOT di Rumah Sakit Cipto Mangunkusumo.

\section{METODE PENELITIAN}

Penelitian ini merupakan deskriptif observasional case series dimana datanya dianalisis secara retrospektif. Sebanyak 28 kasus diterima di instalasi gawat darurat (IGD) Rumah Sakit CIpto Mangunkusumo (RSCM) yang di suspek sebagai NOT. Melalui penelusuran status rekam medis didapatkan 13 kasus NOT yang diterapi dengan metilprednisolon baik secara Intravena maupun oral.

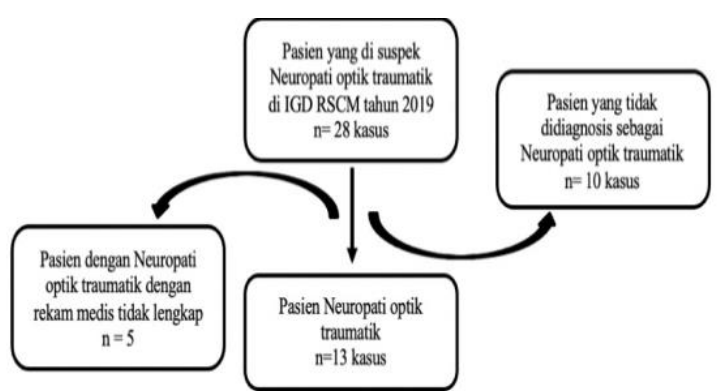

Gambar 1. Alur pengumpulan data sampel

Kriteria inklusi penelitian ini adalah semua pasien baru maupun lama yang datang ke IGD terdiagnosis NOT dan tercatat pada catatan medis di RSCM Kirana Januari sampai Desember 2019. Kriteria eksklusi adalah pasien NOT yang tidak dapat ditelusuri rekam medisnya lebih lanjut.

Data yang diambil dari rekam medis merupakan data sekunder yang berasal dari rekam medis penderita NOT. Data yang dikumpulkan meliputi usia, jenis kelamin, masa awitan trauma, tajam penglihatan, lateralitas, kondisi okular lain, kondisi penyerta lainnya, hasil pencitraan, masa awitan pemberian terapi, jenis terapi, jenis radiologi yang dilakukan dan hasil radiologi serta tajam penglihatan pasca pengobatan kortikosteroid (methylprednisolone)

Analisis data dilakukan dengan statistik deskriptif pada variabel-variabel yang diteliti. Karakteristik akan dianalisis univariat dengan variabel kategorik disajikan dalam 
bentuk proporsi dan variabel numerik disajikan dalam bentuk rerata bila berdistribusi normal dan median (minimum-maksimum) bila distribusinya tidak normal. Gambaran pasien NOT berdasarkan radiologi dan awitan terapi kortikosteroid akan dipaparkan per kasus dengan tabel.

\section{HASIL}

Dari 13 kasus jenis kelamin yang paling banyak terkena adalah laki-laki (76,9\%). Rerata kelompok umur 32,85 \pm 14,67 tahun dengan penglihatan kabur dan perdarahan merupakan gejala yang paling umum, timbulnya trauma dibawah 24 jam (76,9\%), ketajaman penglihatan awal ada persepsi cahaya dan gerakan tangan dengan refleks konsensual negatif (76,9\%). Peningkatan ketajaman penglihatan dengan terapi kortikosteroid awal dibawah 24 jam sebanyak 7 kasus dan lebih dari 24 jam sebanyak 2 kasus.

\begin{tabular}{|c|c|}
\hline Variabel & Jumlah pasien (\%) \\
\hline Umur (Rerata \pm SD) & $32,85 \pm 14,67$ \\
\hline \multicolumn{2}{|l|}{ Jenis Kelamin } \\
\hline Laki-laki & $10(76,9)$ \\
\hline Perempuan & $3(23,1)$ \\
\hline \multicolumn{2}{|l|}{ Jenis Kecelakaan } \\
\hline Jatuh & $2(15,4)$ \\
\hline Kekerasan & $3(23,1)$ \\
\hline Ledakan & $3(23,1)$ \\
\hline Kecelakaan Lalu Lintas & $2(15,4)$ \\
\hline Kecelakaan Kerja & $3(23,1)$ \\
\hline \multicolumn{2}{|l|}{ Keluhan utama } \\
\hline Pengelihatan Kabur & $6(46,2)$ \\
\hline Berdarah & $6(46,2)$ \\
\hline Hilang kesadaran & $1(7,7)$ \\
\hline \multicolumn{2}{|l|}{ Awitan Trauma } \\
\hline$\leq 24 \mathrm{Jam}$ & $10(76,9)$ \\
\hline$>24 \mathrm{Jam}$ & $3(23,1)$ \\
\hline \multicolumn{2}{|l|}{ Tajam Pengelihatan Awal } \\
\hline No Light Perception (NLP) & $4(30,8)$ \\
\hline Light Perception (LP) & $1(7,7)$ \\
\hline Hand Movement (HM) & $4(30,8)$ \\
\hline Finger Counting (FC) & $3(23,1)$ \\
\hline Sulit dinilai & $1(7,7)$ \\
\hline \multicolumn{2}{|l|}{ Jenis Cidera Okular } \\
\hline Open Globe injury & $3(23,1)$ \\
\hline Close Globe injury & $10(76,9)$ \\
\hline \multicolumn{2}{|l|}{ Respon Pupil } \\
\hline RAPD positif & $3(23,1)$ \\
\hline Refleks Konsensuil negative & $10(76,9)$ \\
\hline \multicolumn{2}{|l|}{ Kelainan Retina } \\
\hline Tidak ada kelainan & $9(69,2)$ \\
\hline Komotio Retina & $3(23,1)$ \\
\hline Lain-lain & $1(7,7)$ \\
\hline \multicolumn{2}{|l|}{ Papil Nervus Optik Awal } \\
\hline Hiperemi & $9(69,2)$ \\
\hline Normal & $3(23,1)$ \\
\hline Lain-lain & $1(7,7)$ \\
\hline
\end{tabular}

Tabel 1. Data demografis dan karakteristik klinis pasien Neuropati Optik Traumatik di RSCM tahun 2019

Pada tabel 2 menunjukkan bagaimana gambaran awitan terapi serta radiologi pada kasus yang diterapi kortikosteroid (metilprednisolon). Kasus 1 dan 2 adalah kasus yang menunjukkan perbaikan tajam pengelihatan dengan awitan terapi $\leq 24$ jam dimana hasil radiologi pada masing masing pasien menunjukkan adanya Fraktur orbita serta 
hematome intra dan ekstrakonal pada kasus 1 dan gambaran radiologi yang normal pada kasus 2. Pada awitan terapi $>24$ jam yang menunjukkan perbaikan terlihat sebanyak 7 kasus yaitu kasus4,5,6,8,9,10,13 dengan gambaran radiologi yang bervariasi antara lain Lefort fraktur pada kasus 5 , blow out fraktur pada kasus no 6, emfisema ekstrakonal pada kasus no 8 dan 9, fraktur orbita dan hematome ekstrakonal pada kasus no 10 serta gambaran radiologi yang normal pada kasus no 4 dan 13. Dari seluruh kasus yang mengalami perbaikan tajam pengelihatan, kemajuan tajam pengelihatan tertinggi setelah diberikan terapi kortikosteroid adalah kasus no 8 dimana terapi yang diberikan adalah intravena metilprednisolon dengan awitan terapi $>24$ jam dengan gambaran radiologi emfisema ekstrakonal tanpa adanya fraktur orbita. Pada kasus no 3 menunjukkan satu satunya penurunan tajam pengelihatan dengan awitan terapi > 24 jam dengan gambaran radiologi yang normal. Pada 2 kasus menunjukkan tajam pengelihatan yang menetap setelah diterapi kortikosteroid dengan awitan terapi $\leq 24$ jam pada kasus no 11 dengan gambaran radiologi blow out fraktur dan awitan terapi $>24$ jam pada kasus no 12 dengan gambaran radiologi hematome orbita tanpa adanya fraktur.
Tabel 2. Gambaran Awitan terapi serta radiologi pada kasus yang diterapi kortikosteroid (Metilprednisolon)

\begin{tabular}{|c|c|c|c|c|c|c|c|}
\hline Kasust & VA awal & VA akhir & Jenis Terapi & Awitan terapi & Radiologi & Gambaran & Hasil VA \\
\hline 1 & HM & 0.5160 & IV,Oral & $\leq 24 \mathrm{jam}$ & CT Orbita & $\begin{array}{l}\text { Fraktur orbita } \\
\text { Hematome } \\
\text { Intrakonal } \\
\text { Hematome } \\
\text { Ekstrakonal }\end{array}$ & Perbaikan \\
\hline 2 & HM & $0.5 / 60$ & IV,Oral & $\leq 24 \mathrm{jam}$ & CT Orbita & Nomal & Perbaikan \\
\hline 3 & HM & NLP & IV,Oral & $>24 \mathrm{jam}$ & Ro Orbita & Normal & Penurunan \\
\hline 4 & LP & HM & IV,Oral & $>24 \mathrm{jam}$ & Ro Orbita & Normal & Perbaikan \\
\hline 5 & $2 / 60$ & $3 / 60$ & Oral & $>24 \mathrm{jam}$ & CT Orbita & Lefort Fraktur & Perbaikan \\
\hline 6 & $2 / 60$ & $3 / 60$ & $\mathrm{IV}, \mathrm{Oral}$ & $>24 \mathrm{jam}$ & CT Orbita & Blow out Fraktur & Perbaikan \\
\hline 7 & $\begin{array}{l}\text { sulit } \\
\text { dinilai }\end{array}$ & 2,60 & IV,Oral & $\leq 24 \mathrm{jam}$ & CT Orbita & ZMC Fraktur & $\begin{array}{c}\text { Tidak dapat } \\
\text { dinilai }\end{array}$ \\
\hline 8 & 6160 & 619 & IV,Oral & $>24 \mathrm{jam}$ & CT Orbita & $\begin{array}{l}\text { Emfisema } \\
\text { ekstrakononal }\end{array}$ & Perbaikan \\
\hline 9 & NLP & LP & IV,Oral & $>24 \mathrm{jam}$ & CT Orbita & $\begin{array}{l}\text { Emfisema } \\
\text { ekstrakonal }\end{array}$ & Perbaikan \\
\hline 10 & HM & $0.5 / 60$ & IV,Oral & $>24 \mathrm{jam}$ & CT Orbita & $\begin{array}{l}\text { Fraktur orbita } \\
\text { Hematome } \\
\text { Ekstrakonal }\end{array}$ & Perbaikan \\
\hline 11 & NLP & NLP & IV,Oral & $>24 \mathrm{jam}$ & CT Orbita & Blow out Fraktur & Menetap \\
\hline 12 & NLP & NLP & Oral & $\leq 24 \mathrm{jam}$ & Ro Orbita & Hematome orbita & Menetap \\
\hline 13 & NLP & LP & IV,Oral & $>24 \mathrm{jam}$ & Ro Orbita & Normal & Perbaikan \\
\hline
\end{tabular}

*Computerized Tomography Scan Orbita (CT Orbita)

Radiografi/Rontgen Orbita (Ro Obita)

\section{DISKUSI}

Pasien pada studi ini ditegakkan sebagai pasien NOT dan mendapatkan terapi metilprednisolon baik oral maupun IV yaitu (1) metilprednisolon intravena 1 gram/hari selama 3 hari ( 4 x $250 \mathrm{mg}$ iv), dan dilanjutkan dengan penurunan dosis tiap minggu, atau (2) pemberian metilprednisolon oral $0,8 \mathrm{mg} / \mathrm{kgBB} / \mathrm{hari}$. Dalam studi ini mayoritas kasus yaitu 9 kasus yang menunjukkan perbaikan tajam pengelihatan setelah diterapi metilprednisolon. 1 kasus dengan metilprednisolon oral dan 8 kasus dengan metilprednisolone IV dilanjutkan dengan oral. National acute spinal cord injury study (NASCIS II dan III) menjelaskan adanya manfaat dari pemakaian metilprednisolon dosis tinggi pada terapi cedera tulang belakang akut dimana terapi ini diberikan dalam jangka waktu 8 jam setelah cedera dan selama 24-48 jam. Terapi lain seperti Tirilazad mesylate (steroid sintetis) juga dicoba tetapi metilprednisolon memberikan hasil yang lebih efektif. ${ }^{13,14,15}$ Studi eksperimental lain 
menunjukkan adanya bukti bahwa metilprednisolon dosis tinggi dapat mengurangi kerusakan akson pada saraf optik. ${ }^{15}$ Pada pusat pelayanan yang belum dapat mengerjakan dekompresi saraf optik secara rutin menjadikan steroid dosis tinggi sebagai terapi yang akan dilakukan pada pasien NOT. ${ }^{15}$ Ada 2 kasus yang diterapi dengan awitan $\leq 24$ jam yaitu kasus 1 dan 2 dan ada 7 kasus dengan perbaikan dimana awitan terapi >24 jam (dimana awitan terlama adalah 8 hari pada kasus no 5). Dari 7 kasus dengan perbaikan tajam pengelihan dengan awitan $>24$ jam pada kasus no 8 terjadi perbaikan tajam pengelihatan yang paling baik yaitu dari 6/60 menjadi 6/9. Studi Daniel dkk menyatakan sebanyak $64,7 \%$ pasien mendapatkan terapi inisial > 24 jam pasca trauma dalam dikarenakan admisi awal pasien yang mendekati atau bahkan sudah lebih dari 24 jam pasca trauma. Kondisi pasien yang sudah sempat dibawa ke beberapa layanan kesehatan sebelum tiba di RSCM, prosedur administrasi perujukan, dan juga prosedur persiapan sebelum pemberian terapi steroid dosis tinggi menjadi faktor tertundanya pemberian terapi inisial dalam rentang 24 jam pasca trauma. ${ }^{9}$

Gambaran radiologi pada 9 kasus yang mengalami perbaikan setelah diterapi metilprednisolon bervariasi yaitu ada 4 kasus yang mengalami fraktur orbita serta gambaran radiologi yang tanpa fraktur orbita pada 5 kasus. 1 kasus yang dengan tajam pengelihatan menetap dengan gambaran radiologi blow out fraktur sementara 1 kasus dengan tajam pengelihatan menetap lainnya dan 1 kasus yang mengalami penurunan tajam pengelihatan hanya dilakukan Radiologi/ Ro Orbita dengan hasil hematom orbita pada kasus no 12 dan gambaran normal pada kasus no 3. Beberapa studi menjelaskan keterlibatan fraktur tulang wajah, rima orbita dan posterior orbita berkaitan dengan prognosis tajam penglihatan yang cukup berat, namun tipe fraktur blow-in atau blow-out tidak menunjukkan kaitan yang signifikan. ${ }^{16,17,18}$ Lee dkk menyimpulkan bahwa kebanyakan pasien NOT yang mengalami hematome periorbita dan fraktur dinding orbita yang diterapi dengan kortikosteroid IV dilanjutkan dengan oral memiliki tajam pengelihatan lebih baik dibandingkan hanya dilakukan observasi. ${ }^{19}$

Gambaran radiologi pada 4 kasus yang mengalami perbaikan tajam pengelihatan setelah diterapi metilprednisolone IV dilanjutkan dengan oral menunjukkan adanya gambaran hematome intrakonal dan ekstrakonal pada kasus no 1, emfisema ekstrakonal pada kasus no 8 dan 9 serta hematoma ekstrakonal pada kasus no 10. Studi yang dilakukan oleh Bodanapally dkk Hematome intrakonal dan ekstrakonal, emfisema intrakonal, hematome di bagian posterior bola mata serta fraktur pada kanal optik menjadi prediktor terjadinya NOT pada gambaran CT Scan saat pertama kali datang dengan nilai $\mathrm{p}$ yang signifikan $(\mathrm{p}<$ 0.05 ) dimana hematome intrakonal menjadi prediktor terbaik diantara semuanya ${ }^{13}$

Perbaikan tajam pengelihatan yang terjadi pada 8 kasus termasuk perbaikan ringan dimana hanya meningkat 1 tingkat tajam pengelihatan yaitu dari NLP menjadi LP pada 2 kasus (kasus 9,13), LP menjadi HM pada 1 kasus ( kasus 4), HM menjadi 0,5/60 pada 3 kasus (kasus 1,2,10) dan 1 kasus yang memberikan perbaikan tajam pengelihatan yang baik yaitu dari $6 / 60$ menjadi 6/9 (kasus 8). Kasus NOT no 8 merupakan kasus close globe injury dimana tidak terdapat perdarahan vitreous dan pada gambaran radiologi didapatkan tidak adanya fraktur orbita, emfisema subkutis periorbita hingga rongga orita (ekstrakonal) disertai perdarahan dan fat stranding (inflamasi) yang mendilatasi rongga retrobulbar (intrakonal). Proses inflamasi mendominasi adanya desakan pada bagian retrobulbar sehingga mungkin hal ini mampu menjelaskan kenapa pada kasus no 8 pemberian steroid akan memberikan hasil yang baik walaupun waktu diberikannya 27 jam pasca trauma. Sadeghi-Tari Studi menyatakan 11 dari 12 mata $(91,7 \%)$ yang diterapi dengan metilprednisolon IV dan oral prednisolone mengalami kemajuan 
pengelihatan paling sedikit 1 baris dari tajam pengelihatan. ${ }^{20}$ Studi yang dilakukan Rampriya dkk yang melaporkan 50 kasus dengan NOT menyatakan tidak adanya perbedaan signifikan pada tajam penglihatan pada pasien yang mendapatkan terapi dini metilprenisolon baik IV maupun oral, dimana dari 4 kasus ada 2 kasus yang mengalami peningkatan tajam pengelihatan setelah mendapatkan terapi steroid pada 4 minggu setelah terjadinya trauma. ${ }^{21}$ Hasil yang di dapatkan oleh peneliti di dalam case series ini tidak sesuai dengan Studi IONTS sebelumnya yang menyatakan bahwa baik dosis maupun waktu terapi steroid tidak berpengaruh pada perbaikan tajam pengelihatan. Studi IONTS juga tidak menemukan perbedaan antara terapi steroid dibandingkan dengan intervensi bedah atau tanpa intervensi dengan $52 \%$ yang menerima steroid menunjukkan peningkatan visual dari tiga garis atau lebih dibandingkan $57 \%$ pada kelompok observasi. ${ }^{11,22}$ Dimana terapi pembedahan dan observasi merupakan salah satu penanganan yang dilakukan pada pasien NOT. Peneliti tidak membandingkan pemberian steroid pada pasien NOT dengan pasien NOT yang dilakukan terapi pembedahan (dekompresi) dan pasien NOT yang hanya dilakukan observasi. Selain hal itu keterbatasan penelitian ini adalah dari 13 kasus, 1 kasus dengan penurunan kesadaran tidak dapat dievaluasi peningkatan tajam pengelihatan setelah terapi metilprednisolon. Rekam data tajam pengelihatan pasien juga tidak lengkap sehingga menjadi sulit untuk mendapatkan tajam pengelihatan dalam jangka waktu yang lama. Pasien trauma yang datang ke Instalasi Gawat Darurat RS Cipto Mangunkusomo tidak hanya di rawat di bagian Mata tapi juga bedah trauma, sehingga hal ini mengakibatkan pencatatan status tidak teratur dan beberapa rekam medis tidak dievaluasi di divisi Neuro oftalmologi. Keterbatasan di atas membuat penelitian ini hanya menganalisis 13 kasus dengan tajam pengelihatan yang diperoleh saat terapi selesai.

Saran penelitian antara lain adalah sebaiknya dilakukan penelitian dengan waktu yang lebih lama dan sampel yang lebih besar untuk dapat melihat bagaimana keamanan dan manfaat terapi metilprednisolon, berapa lama onset terapi dan gambaran radiologi dengan peningkatan VA pada kasus TON. Pembuatan formulir khusus pasien trauma yang datang melalui IGD dengan pencatatan data yang lengkap, pemeriksaan klinis lengkap pasien beserta gambaran radiologis disertai dengan formulir khusus pasien TON yang datang ke poliklinik mata Divisi Neuro-oftalmologi.

\section{KESIMPULAN}

$\begin{array}{ccr}\text { Penelitian } & \text { ini } & \text { mampu } \\ \text { menggambarkan } & \text { peran } & \text { terapi }\end{array}$ metilprednisolon yang masih aman pada tatalaksana NOT dan memberikan peningkatan VA (9 dari 13 kasus) bila diberikan pada pasien trauma dengan onset trauma > 24 jam serta gambaran radiologis dengan fraktur orbita atau tanpa fraktur orbita disertai tidak adanya hematoma intraconal, hematom extraconal dan emfisema extraconal.

\section{REFERENCES}

1. Yu B, Ma YJ, Tu YH, Wu WC. Newly onset indirect traumatic optic neuropathy-surgical treatment first versus steroid treatment first. Int Journal Ophthalmol. 2020;13(1):124-128.

2. Samardzic K, Samardzic J, Janjetovic Z, Samardzic I, Sekelj S, Hodzic LL. Traumatic Optic Neuropathy-To Treat or To Observe?. Acta Inform Med. 2012;20(2):131-132.

3. Foroozan RF, Bhatti MT, Falardeau J, Gordon LKG, Lee MS, Subramanian PS, et al. Traumatic Optic Neuropathy. In: Cantor LB, Rapuano CJ, Cioffi GA, editors. Basic Clinical Science and Course. Neuroophthalmology. 5. San Fransisco: American Academy of Ophthalmology; 2014. p. 143-4.

4. Steinsapir KD, Goldberg RA. Traumatic optic neuropathy: an evolving understanding. Am J Ophthalmol. 2011;151(6):928-33. e2. 
5. Singman EL, Daphalapurkar N, White H, Nguyen TD, Panghat L, Chang J, et al. Indirect traumatic optic neuropathy. MMR. 2016;3(1):1-6.

6. Wu N, Yin ZQ, Wang Y. Traumatic Optic Neuropathy Therapy: an Update of Clinical and Experimental Studies. J Int Med Res. 2008; 36: 883 - 9 .

7. Yu WMP, Griffiths PG. Steroids for traumatic optic neuropathy.Cochrane Database Syst Rev. 2013; 6: 1-21.

8. Mahayani NMW, Triningrat AAMP, Manuaba IBP. Karakteristik Pasien Traumatik Optik Neuropati (TON) yang mendapat terapi Kortikosteroid dosis tinggi dibandingkan dengan Observasi di RSUP Sanglah Denpasar Tahun 2013-2015. Med. 2017;48(3):201-205.

9. Daniel H, Nusanti S, Sidik M. Karakteristik, Hasil Terapi dan Prediktor keberhasilan Terapi Pasien Neuropati Optik Traumatik (NOT) Divisi Neurooftalmologi Rumah Sakit Cipto Mangunkusumo. Ophthalmol Ina. 2018;44(1):17-23.

10. Huang TL, Chen N, Lin KH, Tsai RK. Current treatment of traumatic optic neuropathy. Neuro-Ophthalmology Japan. 2014; 31(2): 259-262.

11. Levin LA, Beck RW, Joseph MP, Seiff S, Kraker R, Group IONTS. The treatment of traumatic optic neuropathy: the International Optic Nerve Trauma Study. Ophthalmol. 1999;106(7):1268-77.

12. Bonapally UK, dkk. Traumatic Optic Neuropathy Pediction after Blunt Facial Trauma: Derivation of a Risk Score Based on Facial CT Findings at Admission. Radiol. 2014;272(3):824-830.

13. Bracken MB, Shepard MJ, Collins WF, Holford TR, Young W, Baskin DS, dkk. A randomized, controlled trial of methylprednisolone or naloxone in the treatment of acute spinal-cord injury: results of the Second National Acute Spinal Cord Injury Study. N Eng J Med. 1990;322(20):1405-11.

14. Bracken MB, Sperad MJ,Holford TR, dkk. Administration of methylprednisolone for 24 or 48 hours or trilazard mesylate for 48 hour in the treatment of acute spinal cord injury. Result of the Third National Acute Spinl Cord Injury Randomized Controlled Trial. National Acute Spinal Cord Injury Study. JAMA. 1997;277:1597-604.

15. Das H, Badhu BP, Gautam MA. Indirect traumatic Optic Neuropathy-Restropective Interventional Case Series from a tertiary Care Center in Eastern Nepal. JNMA. 2007;46(2):57-61.

16. Hsieh C-H, Kuo Y-R, Hung H-C, Tsai H$\mathrm{H}$, Jeng S-F. Indirect traumatic optic neuropathy complicated with periorbital facial bone fracture. J Trauma Acute Care Surg. 2004;56(4):795-801.

17. Tsai H-H, Jeng S-F, Lin T-S, Kueh N-S, Hsieh $\mathrm{C}-\mathrm{H}$. Predictive value of computed tomography in visual outcome in indirect traumatic optic neuropathy complicated with periorbital facial bone fracture. Clin Neurol Neurosurg. 2005;107(3):200-6.

18. Reddy RP, Bodanapally UK, Shanmuganathan K, Van der Byl G, Dreizin D, Katzman L, et al. Traumatic optic neuropathy: facial CT findings affecting visual acuity. Emerg Radiol. 2015;22(4):351-6.

19. Lee KF, Nor IM, Yaakub A, Hitam WHW. Traumatic optic neuropathy: a review of 24 patients. Int J Ophthalmol. 2010;3(2):175-178.

20. Sadeghi-Tari A, Lashay AR, Tabassi A. Visual Outcome of traumatic optic neuropathy in patients treated with intravenous megadose of steroids. Acta Med Iran. 2005;43(2):110-114.

21. Rampriya C, Visalakshi S, Sudha N. A Case series on Traumatic Optic Neuropathy. IOSRJDMS. 2019:18(5):43-47.

22. Saxena R, Singh D, menon V. Controversies in neuro-ophthalmology: Steroid theraphy for the Traumatic Optic Neuropathy. Indian J Ophthalmol. 2014;62:1028-30. 